\title{
Phenotypic Variation Profile of Marsilea crenata Presl. Cultivated in Water and in the Soil
}

\author{
Mangestuti Agil, Idha Kusumawati, and Neny Purwitasari \\ Department of Pharmacognosy and Phytochemistry, Faculty of Pharmacy, Airlangga University, Indonesia \\ Correspondence should be addressed to Mangestuti Agil; mmangestuti@yahoo.com
}

Received 3 March 2017; Accepted 1 June 2017; Published 6 August 2017

Academic Editor: William K. Smith

Copyright (C) 2017 Mangestuti Agil et al. This is an open access article distributed under the Creative Commons Attribution License, which permits unrestricted use, distribution, and reproduction in any medium, provided the original work is properly cited.

\begin{abstract}
The aim of this research was to investigate possible phenotypic variation profile of Marsilea crenata Presl. cultivated in water and in the soil, to find alternative cultivation techniques to fulfill the increasing demand for pollutant-free plants. Phenotypic profile was investigated through macroscopic and microscopic examinations of all plant parts, and phytochemical screening on the ethanol extract of the leaves using thin layer chromatography technique was conducted to detect the terpenoid constituents. Results showed a variation of phenotypic profiles in the macroscopic examination caused by different cultivation methods. Phytochemical screening showed spots of terpenoid compounds with different color intensity. No differences were found in the microscopic examination of the leaves, petioles, and stems. Since major profile changes did not occur, M. crenata is recommended to be cultivated in water as its original habitat by providing a better caring and quality of water. Due to its phytoremediation property, it is necessary to grow M. crenata in pollutant-free water.
\end{abstract}

\section{Introduction}

Marsilea crenata Presl. is an aquatic plant and has been used through generations by people of Surabaya City, East Java Province of Indonesia, as vegetables. It is locally named semanggi, and people name it semanggi Surabaya, to correlate it with the name of the city.

Semanggi Surabaya itself is a popular dish from East Java Province and prepared from steamed semanggi leaves served with a special peanut sauce [1]. The leaves have been used empirically to prevent osteoporosis among postmenopausal women, but scientific research to investigate its health benefits is lacking. Study on the ethanol extract of the leaves using radioimmunoassay technique found its estradiol-like chemical contents. Research conducted in mice using ethanol extract of the leaves combined with axial weight-bearing exercise showed its antiosteoporotic activity. It showed its capacity in the prevention of imbalances of bone remodelling in human and mice [2].

Further investigation was carried out using a fraction of n-hexane leaf extract to study its antiosteoporotic activity in osteoporotic mice. Result showed improvement in trabecular femur and vertebrae bone masses of osteoporotic mice [3].
Further isolation and characterization of terpenoid compounds in n-hexane and petroleum ether leaf extracts were conducted [4]. Isolation of the active compound found some steroid compounds, and this opens the possibility of using $M$. crenata as a source of phytoestrogen [5].

In vitro study of $n$-hexane leaf extract using cell lines showed its antiosteoporotic activity [6].

The plant also contained various vitamins and minerals, such as calcium, iron, magnesium, $\mathrm{Fe}$, and vitamins $\mathrm{A}$ and $\mathrm{C}$ [7]. The leaf and petiole were reported to contain protein, $\beta$-carotene, fat, and fiber [8].

A study was conducted on the plant grown in murky and contaminated waters in the rice field at Benowo District, East Java Province, and found high lead and mercury contents in the leaves. This was certainly caused by its phytoremediation property $[1,9]$. The district itself was recognized as the source of the plants for commercial purpose. Therefore, research to study the growing method in the soil was conducted to find a better cultivation technique.

Result showed the ability of M. crenata to grow in the soil and was followed by standardization to find its specific and nonspecific parameters [10]. 
But, further study is still needed to find right cultivation techniques, in order to obtain pollutant-free plants.

The objective of the research was to study phenotypic variation profiles of $M$. crenata cultivated in water and in the soil. Phenotypic profiles were investigated through microscopic examinations of leaves, petioles, stems, and roots. Phytochemical screening was conducted to study the terpenoid constituents of the plant using thin layer chromatography technique [10].

\section{Materials and Methods}

\subsection{Materials}

2.1.1. Plant Materials. Plants were harvested from water and soil cultivations in April 2016. Plants harvested from the rice field at Benowo District, East Java Province, were being used as a control.

Determination was conducted at Purwodadi Botanical Garden, East Java, Indonesia.

2.1.2. Extract of Dried Powdered Leaves. Leaves were dried in an oven at $50^{\circ} \mathrm{C}$ and powdered and extracted with $96 \%$ ethanol in a sonic bath for 20 minutes.

2.2. Cultivation. Cultivation was conducted in South Surabaya City, East Java Province, Indonesia, in January 2016. Seeds were obtained from Benowo District, Surabaya.

(1) In water, cultivation was conducted in concrete pots size $58 \times 49 \times 16 \mathrm{~cm}$ filled with ready-made mixtures of soil and composts up to half height of the pots. Water was added to fill up the surface of the pots to provide muddy water as in their original habitat. It allowed settling for 24 hours before plant seedling was planted.

(2) In the soil, cultivation was conducted in clay pots size $63 \times 26 \times 18$ filled with ready-made mixtures of soil and composts. Plants were watered twice a day (morning and afternoon).

All pots were exposed under full sunlight during their entire growth as in their original habitat in rice fields.

2.3. Phenotypic Profiles. Phenotypic profiles were studied through morphological and anatomical examinations. Morphological examination was conducted on leaf, petiole, stem, and root of the plant. Anatomical examination of the plant was conducted by observing the cross sections of leaf, petiole, and stem using light microscope.

2.4. Phytochemical Screening. Phytochemical screening was conducted by thin layer chromatography technique to study the terpenoid constituents of the leaves.

$96 \%$ ethanol extract of powdered leaves from water and soil cultivations was used to detect terpenoid contents using n-hexane : ethyl acetate $(4: 6)$ as mobile phase. Anisaldehyde sulphuric acid was used as spray reagent.
TABLE 1: Morphology of leaves, petioles, stems, and roots of $M$. crenata cultivated in the soil and in water.

\begin{tabular}{|c|c|}
\hline Leaf type & $\begin{array}{l}\text { Compound, } 4 \text { leaflets on top of each } \\
\text { petiole, cuneate, leaf tip truncate, leaf base } \\
\text { acute/obtuse, margin integer }\end{array}$ \\
\hline Petiole & Round, fine surface hair, light green \\
\hline Stem & $\begin{array}{c}\text { Round, fine surface hair, brown, grown above or just } \\
\text { below the soil surface }\end{array}$ \\
\hline Roots & Fibrous, appearing from each node, brown \\
\hline
\end{tabular}

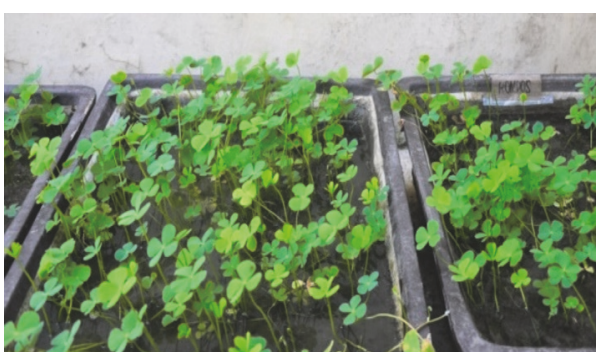

FIGURE 1: Cultivation in water in concrete pots.

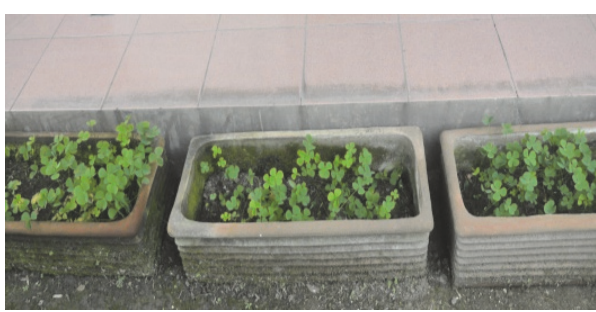

FIGURE 2: Cultivation in soil in clay pots.

\section{Results and Discussions}

3.1. Cultivation. Cultivation in concrete pots was shown in Figure 1. Figure 2 showed cultivation in clay pots. Figure 3 showed cultivation in the rice field.

\subsection{Phenotypic Profiles}

3.2.1. Morphological Examination. The plant has pinnately compound leaves with 4 cuneate leaflets, petioles rounded and finely hairy on the surface (Table 1). Morphological differences were observed through length and diameter of petioles, diameter of stems, length and density of roots, and distances between nodes of stems (Table 2). Figures 4, 5, and 6 presented different petiole's length of water and soil cultivated plants. Petiole was longer in $M$. crenata cultivated in soil compared to water cultivation (Figure 5). Figures 4 and 6 showed petioles of water cultivated plants in concrete pots that were relatively longer compared to water cultivation in the rice fields.

Figure 7 showed that differences of root profile grew from the stems, distances between nodes, diameter of stems, and length of petioles in water and soil cultivations. Fibrous roots appeared from each node of the stems, and each cultivation 
TABLE 2: Morphological differences of leaves, petioles, and roots of M. crenata cultivated in the soil and water.

\begin{tabular}{lccc}
\hline Plant part & & Observation & \\
& Cultivation in water in concrete pots & Cultivation in the soil & Cultivation in water in rice field \\
\hline Leaf & Light green & Light green & Light green \\
Color & $3.5 \times 3.5 \mathrm{~cm}$ & $4.5-5 \times 4.5-5 \mathrm{~cm}$ & $3.0 \times 3.0 \mathrm{~cm}$ \\
Diameter of compound leaves & $1.7 \mathrm{~cm}$ & $2.2 \mathrm{~cm}$ & $1.7 \mathrm{~cm}$ \\
Size of leaf tip & $0.5 \mathrm{~cm}$ & $0.7 \mathrm{~cm}$ & $0.4 \mathrm{~cm}$ \\
Size of leaf base & Thin & Thin & Thin \\
Thickness & $12-15 \mathrm{~cm}$ & $20-24 \mathrm{~cm}$ & $11.5-15.5 \mathrm{~cm}$ \\
\hline Petiole & Greater & Smaller & Greater \\
Length & Long, vigorous, dense & Short and sparse & $3-8 \mathrm{~cm}$ \\
Diameter & $8-17 \mathrm{~cm}$ & $0.5-1 \mathrm{~cm}$ & $5-5.5 \mathrm{~cm}$ \\
\hline Roots & $1-3 \mathrm{~cm}$ & and sparse \\
\hline Distance between nodes of & & 3 \\
stems & & & 3 \\
\hline
\end{tabular}

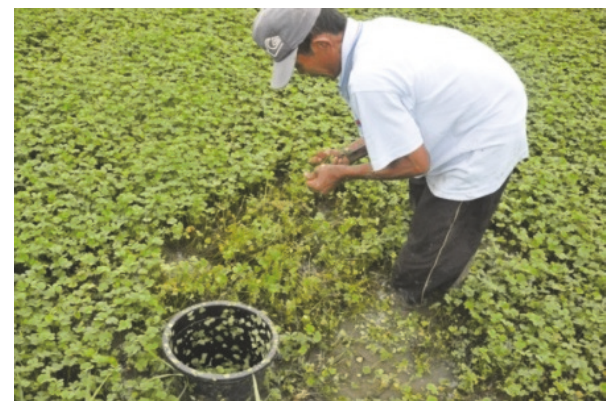

Figure 3: Cultivation and harvest in the rice field at Benowo District, East Java Province.

method showed different root appearances. Roots are longer and more vigorous in water cultivated $M$. crenata in concrete pots compared to water cultivation in the rice fields and in the soil. Figure 10 showed a different profile of roots in soil cultivation caused by a short node distance.

All cultivation methods yielded different distances between nodes of stems. Figure 9 showed that the longest distance occurred in water cultivation in the rice field, and the shortest was in soil cultivation (Figure 10). Nodes distances of water cultivation in concrete pots are shorter compared to the rice field cultivation (Figure 8).

Both cultivations in water showed same diameter of the petioles and stems (Figures 11 and 12), while smaller diameters were found in the soil cultivation (Figure 13).

Leaf size of both water cultivations was shown to be relatively smaller in diameter and length compared to soil cultivation (Figure 14).

3.2.2. Anatomical Examination. Anatomical examination through cross-section of the leaf, petiole, and stem was studied. Results showed that there were not any differences in anatomical profiles of $M$. crenata cultivated in water and soil. It showed that morphological differences did not cause

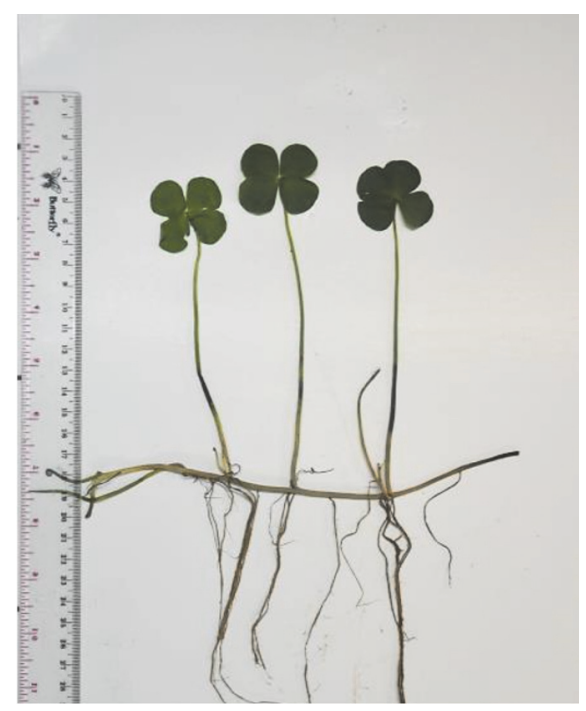

FIGURE 4: $M$. crenata cultivated in water.

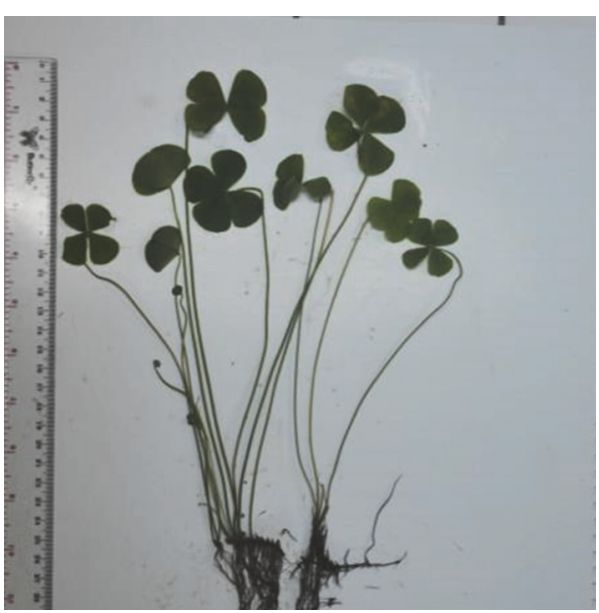

FIgURE 5: M. crenata cultivated in the soil. 


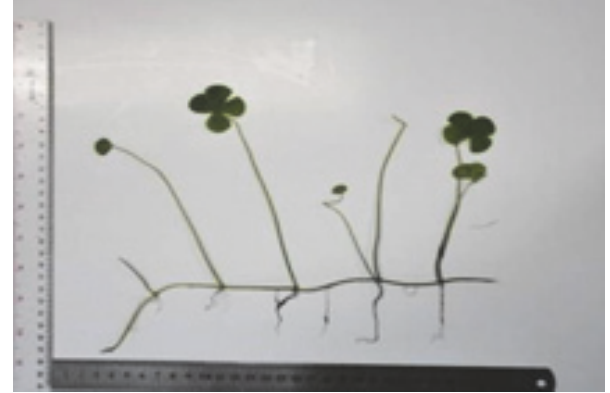

Figure 6: $M$. crenata cultivated in water in the rice field.

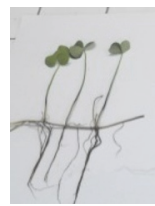

(a)

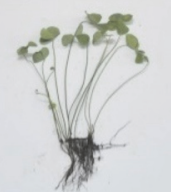

(b)

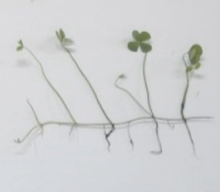

(c)
Figure 7: Petioles, stems, and roots of M. crenata cultivated in water in the pot (a), soil (b), and water in the rice field (c).

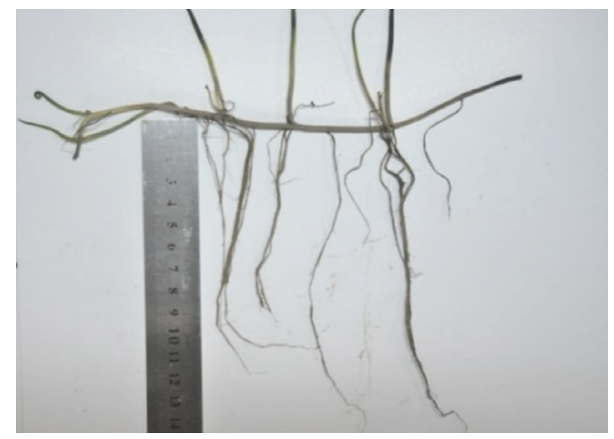

FIgURE 8: Roots of cultivated M. crenata in water in concrete pots.

any changes on the anatomical structures of leaves, petioles, and stems.

Leaf. Lower epidermis of the leaf showed a layer of epidermal cells with papillae (Figure 15).

Petiole. Petioles of M. crenata were composed of epidermis, aerenchyma, septa, inner cortex with parenchymatous cells, and vascular bundle (Figure 16).

Stem. Stems of $M$. crenata cultivated in the soil grew above or just below the soil surface, while those of water cultivation were emerged under the water. It composed of epidermis, aerenchyma, septa, inner cortex with sclerenchyma and parenchymatous cells, and vascular bundle (Figure 17). Aerenchyma was found in aquatic plants and provided aeration for the plan.

3.3. Phytochemical Screening. Phytochemical screening was conducted using thin layer chromatographic technique to

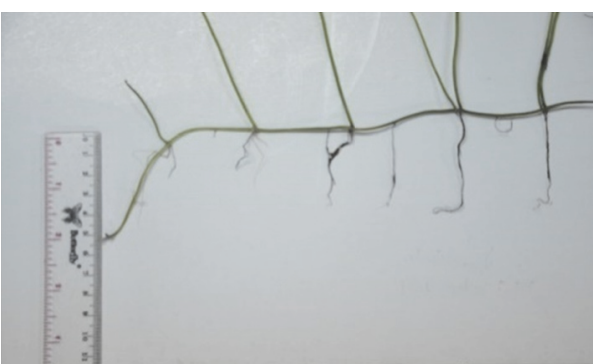

FIGURE 9: Roots of cultivated M. crenata in water in the rice field.

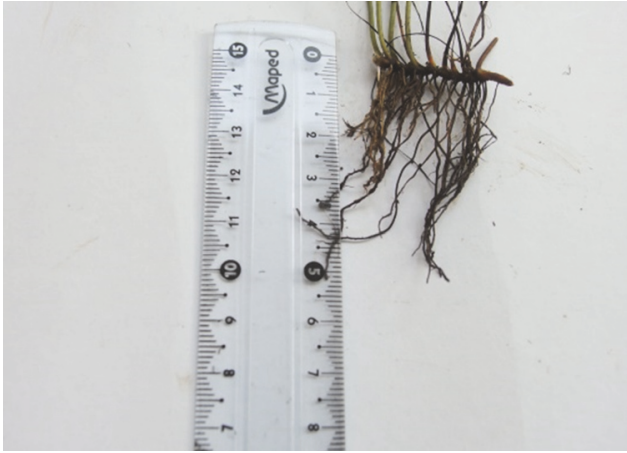

FIGURE 10: Root of cultivated M. crenata in soil in a clay pot.

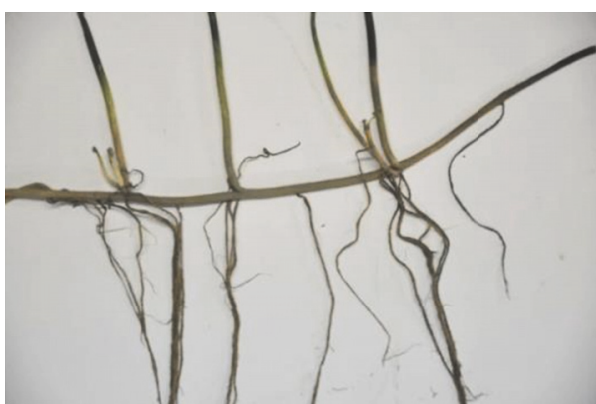

FIGURE 11: Stem, root, and petiole of M. crenata in water in concrete pots.

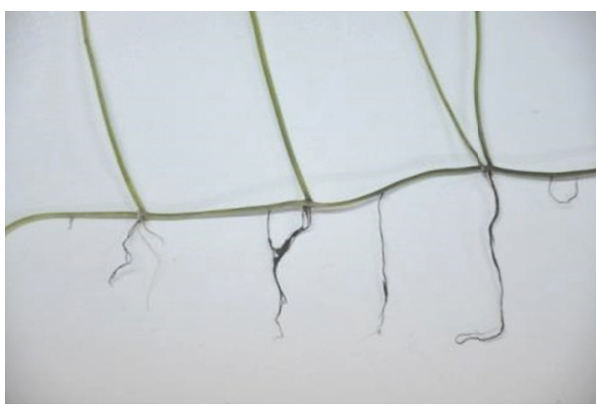

FIGURE 12: Stem, root, and petiole of cultivated M. crenata in water in the rice fields.

study the terpenoid constituents of $96 \%$ ethanol extract of the leaves. Results showed that all ethanol extracts showed some violet spots of terpenoid compounds with the 


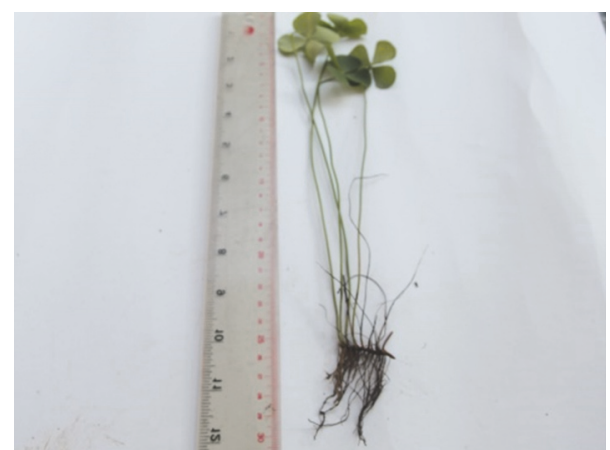

FIGURE 13: Stem, root, and petiole of cultivated M. crenata in the soil.

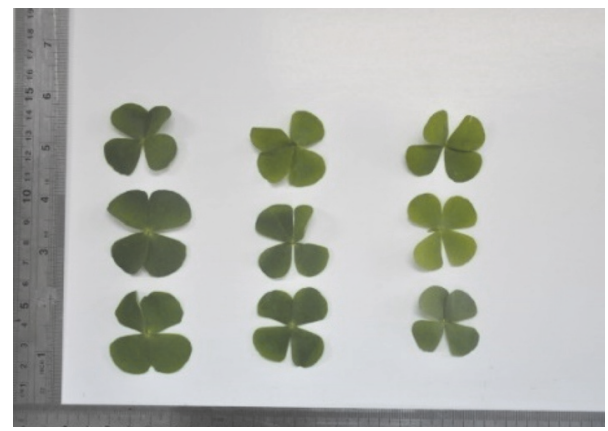

(a)

(b)

(c)

FIGURE 14: Leaves of M. crenata cultivated in the soil (a), in water in concrete pots (b), and in the rice field (c).

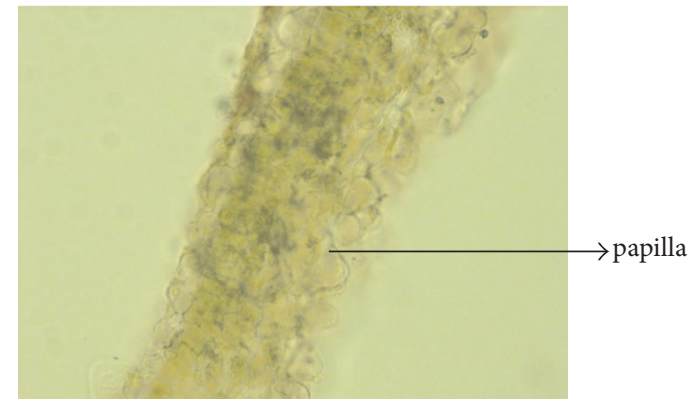

FIGURE 15: Cross section of M. crenata Presl. leaves showed papillae of lower epidermal cells using light microscope (400x).

same Rf values, where soil cultivated leaves showed more intensive colors of spots with $\mathrm{Rf}$ values of $0.98,0.93$, and 0.43 (Figure 18).

Research found a phenotypic variation profile caused by different cultivation methods of $M$. crenata. Such variation showed plant's response to changes through environmentally induced shifts of its phenotype [11, 12]. It could be seen from the sizes of petioles, stems, roots, and leaves. Water cultivation in concrete pots showed longer and more vigorous roots compared to water cultivation in the rice field and soil. This was caused by better caring that give better growing environment compared to cultivation in the rice field in murky and contaminated waters at Benowo District, where farmers

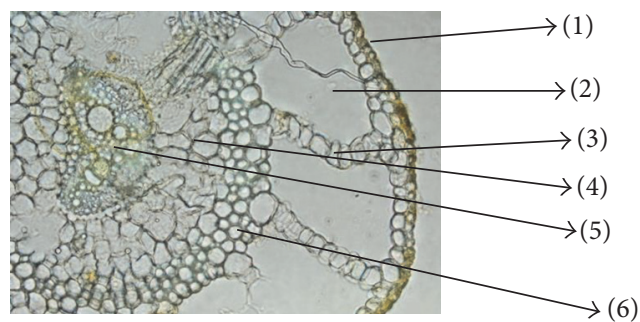

FIGURE 16: Cross section of the petiole of $M$. crenata. (1) = epidermis, (2) = aerenchyma, $(3)=$ septum,$(4)=$ parenchyma, $(5)=$ vascular bundle, and $(6)=$ inner cortex.

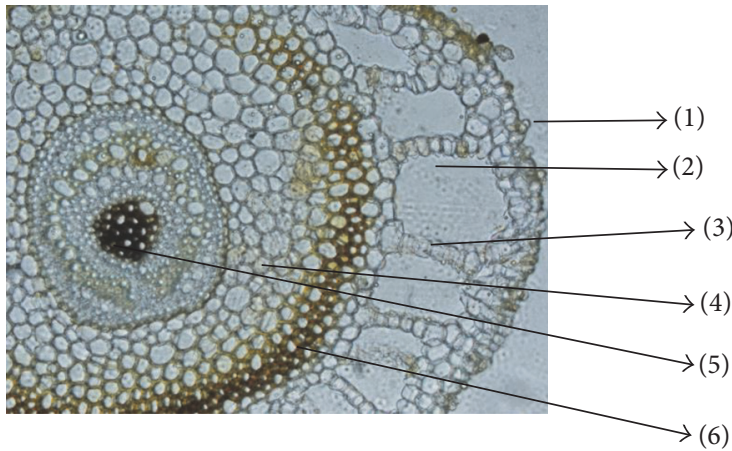

FIGURE 17: Cross section of the stem of $M$. crenata. (1) = epidermis, (2) = aerenchyma, (3) = septum, $(4)$ = parenchyma, $(5)$ = vascular bundle, and $(6)=$ sclerenchyma.

used pesticides [13]. Longer, denser, and more vigorous roots proved the plant's ability to enhance nutrient uptake [14]. Soil cultivation showed longer petioles, shortest distance between nodes, and more intensive spot colors of terpenoid compounds in the ethanol extract of the leaves. Such accumulation of metabolites was possibly caused by stresses occurring during the changing of cultivation method. This indicated the secondary metabolite's role in the adaptation to the changing of environment and overcoming stress conditions [13].

Since major profile change did not occur, it is indicated that $M$. crenata was best cultivated in water as its original habitat as an aquatic plant.

\section{Conclusion and Recommendation}

It is concluded that $M$. crenata was best cultivated in water as its original habitat as an aquatic plant. Cultivation should be conducted by giving a special attention to better caring using pollutant-free water. For safety reasons, it is not recommended to use the plant's phytoremediation property for water or soil cleaning purposes $[15,16]$. This was based on the fact that people consumed the leaves as vegetable, and vegetable rich in heavy metal could cause serious health problems in humans $[17,18]$. Further research is still needed to find a better cultivation method for obtaining pollutant-free plants. 


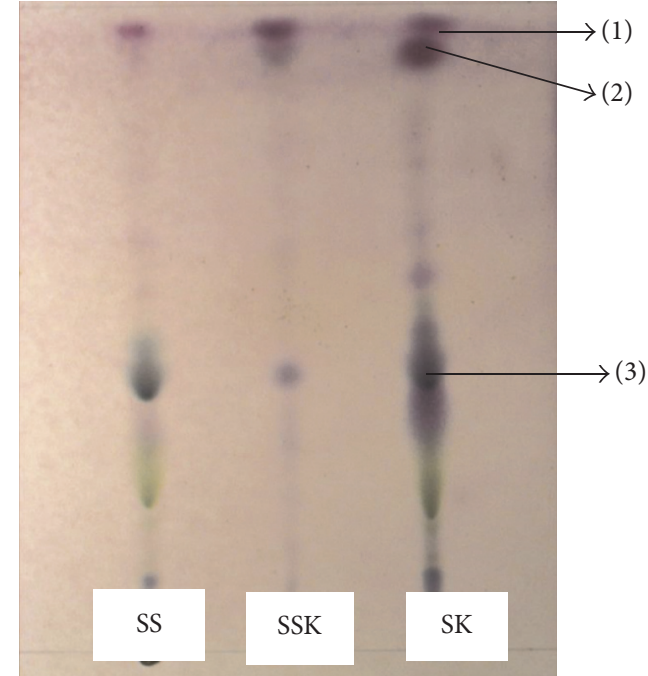

FIGURE 18: Thin layer chromatogram of $96 \%$ ethanol extracts of powdered leaves of $M$. crenata from water cultivation in the rice field (SS), water cultivation in concrete pots (SSK), and soil cultivation (SK). Rf $1=0.98, \operatorname{Rf} 2=0.93$, and Rf $3=0.43$. Stationery phase: TLC silica gel 60 GF 254. Mobile phase: n-hexane : ethyl acetate $=4: 1$. Spray reagent: anisaldehyde sulphuric acid.

\section{Conflicts of Interest}

The authors stated that there are no conflicts of interest regarding the publication of this paper.

\section{Acknowledgments}

This work was supported by Research Grant of Faculty of Pharmacy Airlangga University 2016 (Dean Decree no. 67/UN3.1.5./2016).

\section{References}

[1] A. Mangestuti, "Semanggi and osteoporosis," vol. 1, pp. 9-24, Indomedia Pustaka, Yogyakarta, Indonesia, 1st ed edition, 2016.

[2] L. Hening, Combination of physical exercise and Marsilea crenata Presl. leaves in combating imbalance of bone remodelling of post-menopausal women through the role of estrogen receptor and osteoblast cells [Dissertation], Program Pascasarjana Universitas Airlangga, Surabaya, Indonesia, 2007.

[3] N. Y. Aemi, "Antiosteoporotic activity test of n-hexane fraction of Marsilea crenata Presl. leaves in the enhancement of trabecular bone density of female mice," Surabaya, Indonesia, Fakultas Farmasi Universitas Airlangga, Essay, 2012.

[4] M. Burhan, "Isolation of terpenoid compound of n-hexane extract of Marsilea crenata Presl. Leaves," Surabaya, Indonesia, Fakultas Farmasi Universitas Airlangga, Essay, 2012.

[5] N. I. S. Adi, "Isolation of terpenoid compound of petroleum ether fraction of n- hexane extract of Marsilea crenata leaves," Surabaya, Indonesia, Fakultas Farmasi Universitas Airlangga, Essay, 2012.

[6] M. Burhan, A. Mangestuti, and L. Hening, "Phytochemical Assessment on n-Hexane Extract and Fractions of Marsilea crenata Presl. Leaves through GC-MS," Traditional Medicine Journal, vol. 21, no. 2, pp. 77-85, 2016.

[7] "Marsilea crenata (PROSEA)," 2017, http://uses.plantnet-project .org/e/index.php?title=Marsilea_crenata_(PROSEA)\&oldid= 21930730.

[8] "Analisis mikroskopis dan vitamin semanggi air marsilea crenata presl (marsileaceae)," 2017, http://repository.ipb.ac.id/ handle/123456789/14213.

[9] A. Y. Nurhayati, Y. C. Hariadi, and P. Lestari, "Early detection of lead stress on marsilea crenata using biolectricity measurement," Procedia Environmental Sciences, vol. 28, pp. 57-66, 2015.

[10] Afidha A. P., "Standardization of Marsilea crenata Presl. cultivated in soil in Rungkut area of Surabaya," Surabaya, Indonesia, Fakultas Farmasi Universitas Airlangga, Essay, 2012.

[11] A. B. Nicotra, O. K. Atkin, S. P. Bonser et al., "Plant Phenotypic plasticity in a changing climate," Trends in Plant Science, vol. 15, no. 12, pp. 684-692, 2010.

[12] G. R. Cramer, K. Urano, S. Delrot, M. Pezzotti, and K. Shinozaki, "Effects of abiotic stress on plants: a systems biology perspective," BMC Plant Biology, vol. 11, article 163, 14 pages, 2011.

[13] A. Ramakrishna and G. A. Ravishankar, "Influence of abiotic stress signals on secondary metabolites in plants," Plant Signaling and Behavior, vol. 6, no. 11, pp. 1720-1731, 2011.

[14] Y. Wang, K. Thorup-Kristensen, L. S. Jensen, and J. Magid, "Vigorous root growth is a better indicator of early nutrient uptake than root hair traits in spring wheat grown under low fertility," Frontiers in Plant Science, vol. 7, no. 2016, article no. 865, 2016.

[15] B. Suresh and G. A. Ravishankar, "Phytoremediation: a novel and promising approach for environmental clean-up," Critical Reviews in Biotechnology, vol. 24, no. 2-3, pp. 97-124, 2004.

[16] M. I. Lone, Z.-L. He, P. J. Stoffella, and X.-E. Yang, "Phytoremediation of heavy metal polluted soils and water: progresses and perspectives," Journal of Zhejiang University: Science B, vol. 9, no. 3, pp. 210-220, 2008.

[17] B. Dinham, "Growing vegetables in developing countries for local urban populations and export markets: problems confronting small-scale producers," Pest Management Science, vol. 59, no. 5, pp. 575-582, 2003.

[18] R. Singh, N. Gautam, A. Mishra, and R. Gupta, "Heavy metals and living systems: an overview," Indian Journal of Pharmacology, vol. 43, no. 3, pp. 246-253, 2011. 

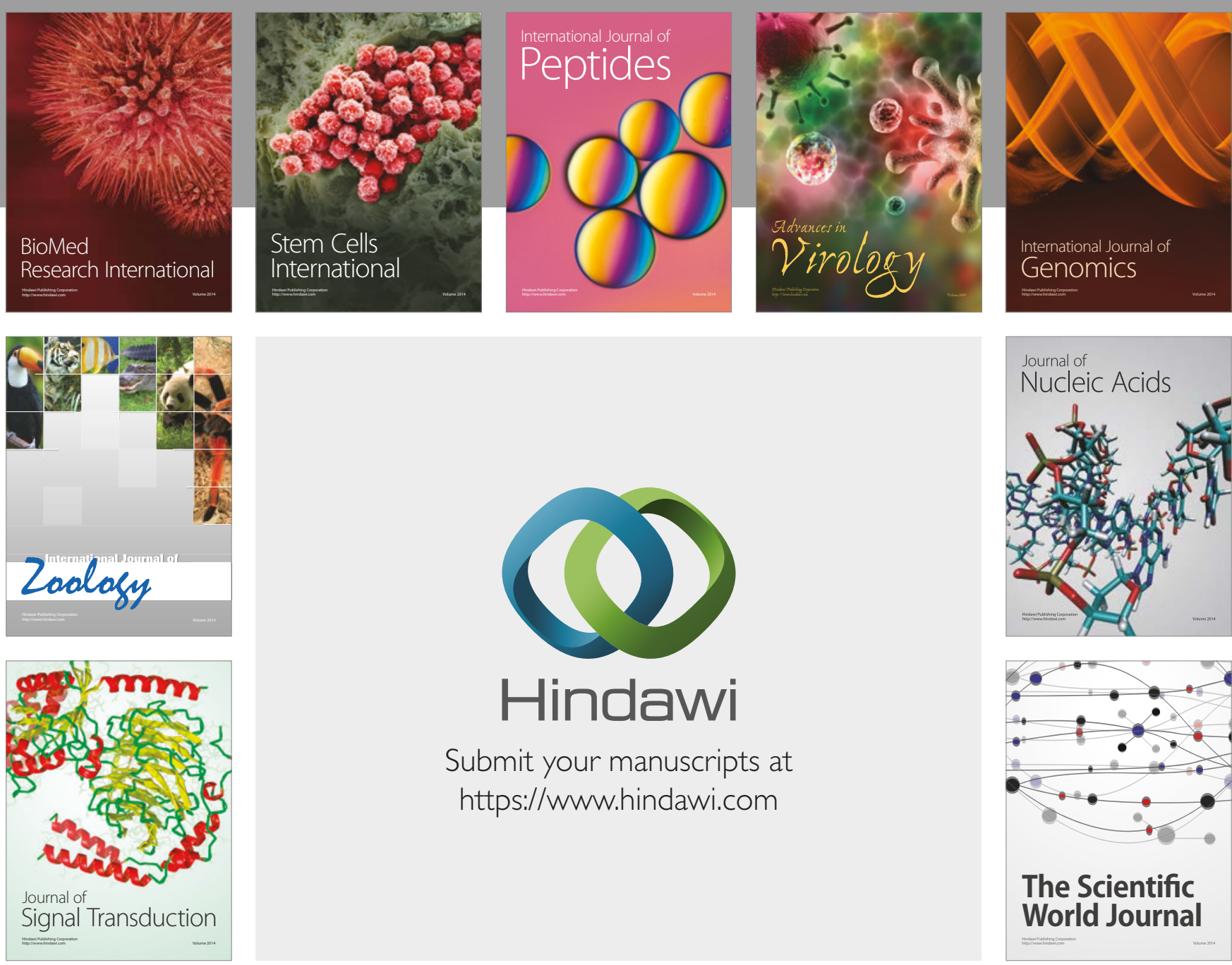

Submit your manuscripts at

https://www.hindawi.com
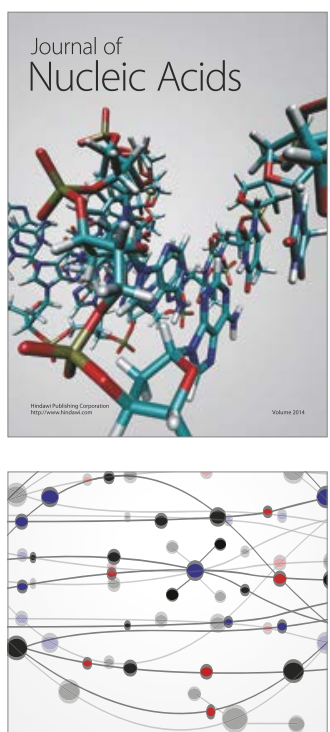

The Scientific World Journal

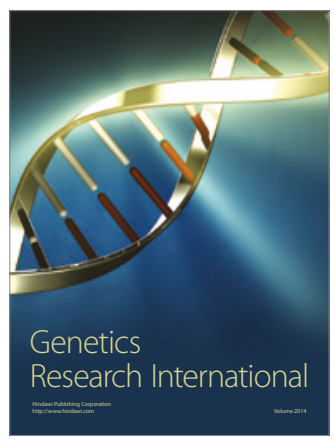

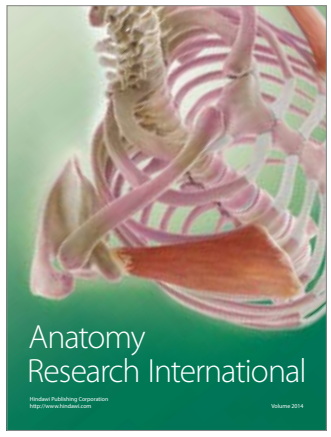

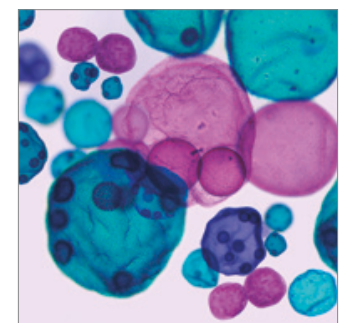

International Journal of Microbiology
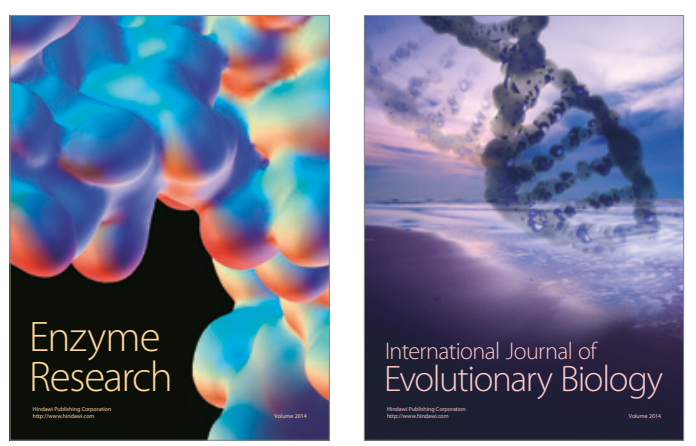
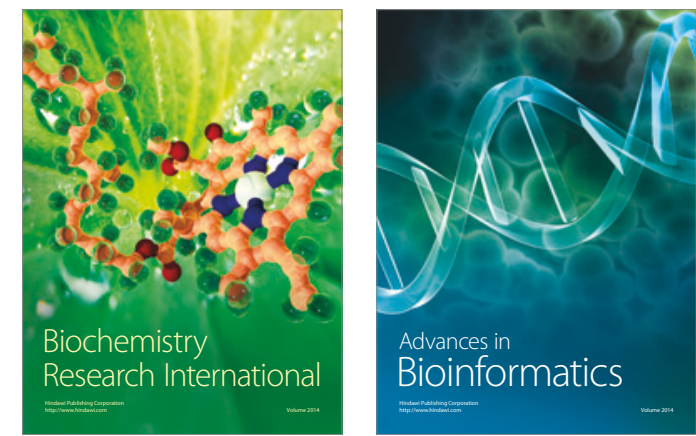

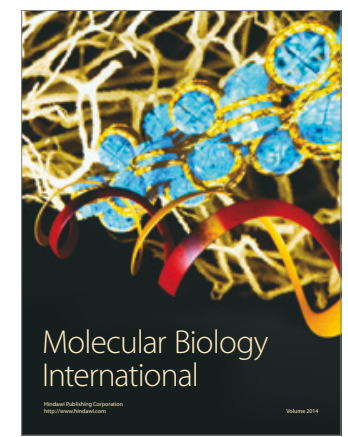

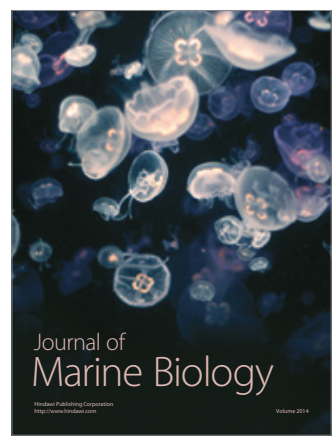

